\title{
Deep sequencing with longitudinal sampling of a VRC01-like-antibody response in a chronically infected individual
}

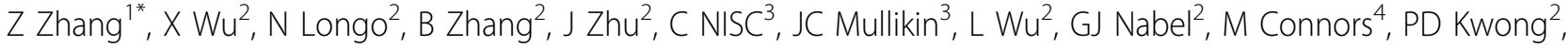 \\ JR Mascola², L Shapiro ${ }^{1}$
}

From AIDS Vaccine 2012

Boston, MA, USA. 9-12 September 2012

\section{Background}

VRC01-like antibodies use heavy chain mimicry of the CD4-receptor to achieve effective neutralization of HIV-1. The VRC01-like antibodies that have been observed in a number of HIV-1-infected individuals (i) display extensive somatic changes (70-100 nucleotide changes in VH-gene), (ii) can be detected only after several years of infection, (iii) derive from VH1-2, and (iv) are compatible with several different heavy J chains and different light chains.

\section{Methods}

To understand the persistence, evolution, and lineage of VRC01-like antibodies, we sampled PBMCs from donor 45 , the source of VRC01 and VRC03 antibodies, at approximately yearly intervals over a 15 -year period, and performed deep sequencing on the heavy and light chain variable portions of expressed antibodies. Anti-idiotypic antibodies were used to correlate mRNA levels of antibodies identified by the deep sequencing with expressed levels of these antibodies in serum.

\section{Results}

High expression levels of VRC01-like antibody sequences persisted over the entire 15-year period. Multiple lineages of VRC01-like antibodies were detected at each time point, and some of these, in particular the lineages that include VRC01 and VRC03, persisted over multiple time points, and displayed extensive branching in their evolution.

${ }^{1}$ Columbia University, New York, NY, USA

Full list of author information is available at the end of the article

\section{Conclusion}

Deep sequencing provides a means to define the genetic record of the lineage and maturation of antibodies effective at neutralizing HIV-1. Precise definition of the natural ontogeny of broadly neutralizing antibodies may be essential in defining appropriate strategies to elicit such antibodies in vaccine settings.

\section{Author details \\ ${ }^{1}$ Columbia University, New York, NY, USA. ${ }^{2}$ Vaccine Research Center, NIAID, $\mathrm{NIH}$, Bethesda, MD, USA. ${ }^{3}$ National Human Genome Research Institute, Bethesda, MD, USA. ${ }^{4}$ National Institute of Allergy and Infectious Diseases, $\mathrm{NIH}$, Bethesda, MD, USA.}

Published: 13 September 2012

doi:10.1186/1742-4690-9-S2-036

Cite this article as: Zhang et al.: Deep sequencing with longitudinal sampling of a VRC01-like-antibody response in a chronically infected individual. Retrovirology 2012 9(Suppl 2):O36.

Submit your next manuscript to BioMed Central and take full advantage of:

- Convenient online submission

- Thorough peer review

- No space constraints or color figure charges

- Immediate publication on acceptance

- Inclusion in PubMed, CAS, Scopus and Google Scholar

- Research which is freely available for redistribution 